\title{
Skin prick test results in patients with chronic allergic rhinitis: Housewives are risky occupational group for the development of allergic rhinitis due to house dust mites
}

\section{Kronik alerjik rinitli hastalarda cilt prick test sonuçları: Ev hanımları ev tozu akarlarına bağlı alerjik rinit gelişimi için riskli meslek grubundadır}

\author{
(1) Tarkan Özdemir, ${ }^{1}$ (D) Benan Kasapoğlu, ${ }^{2}$ (1) Mustafa Hamidullah Türkkanı, ${ }^{3}$ \\ (1) Çiğdem Özdilekcan, ${ }^{1}$ (1) Fuat Erel ${ }^{4}$ \\ 'Department of Pulmonology, University of Health Sciences, Dr. Abdurrahman Yurtaslan Oncology Training and Research Hospital, \\ Ankara, Turkey \\ ${ }^{2}$ Department of Internal Medicine, University of Health Sciences, Dr. Abdurrahman Yurtaslan Oncology Training and Research Hospital, \\ Ankara, Turkey \\ ${ }^{3}$ Department of Pulmonology, Sincan Dr. Nafiz Körez State Hospital, Ankara, Turkey \\ ${ }^{4}$ Department of Pulmonology, Balıkesir University Faculty of Medicine, Balıkesir, Turkey
}

\begin{abstract}
Introduction: Allergic Rhinitis (AR) is a common disorder that negatively effects the quality of life with symptoms due to the inflammation of nasal epithelium. Objective of this study is to determine the general demographical and clinical features of patients with $A R$, who had positive skin prick test (SPT) results.

Methods: Patients diagnosed as AR with positive SPT results were analyzed. The allergens tested were: grasses, cereals+grasses, trees 1 (early flowering), trees 2 (late flowering), house-dust mites (Dermatophagoides pteronyssinus (DP), Dermatophagoides farinae (DF), tyrophagus putrescentiae (TP), lepidoglyphus destructor (LD) and acarus siro (AS).

Results: Of the total 202 patients, 145 female (with a mean age of $32.42 \pm 12.81$ years) and 57 male (with a mean age of $28.44 \pm 11.5$ years) were included in the study. The most common allergens determined were; DF, DP, cereals+grasses and grasses. Tyrophagus significantly was more common in females $(p=0.04)$. Nasal discharge, dyspnea, itching and weakness-tiredness were reported to be more common in females compared with males. DF, DP, TP and LD were statistically significantly more common in housewives $(p<0.05)$. Dyspnea, wheezing and itching were statistically significantly more common in housewives $(p<0.05)$.
\end{abstract}

Discussion and Conclusion: Housewives are risky occupational group for the development of allergic rhinitis due to house dust mites. Keywords: Allergic rhinitis; housewives; occupational disease; skin prick test.
Özet

Amaç: Alerjik rinit (AR), nazal epitelyum inflamasyonuna bağlı olarak ortaya çıkan ve yaşam kalitesini olumsuz yönde etkileyen semptomlarla karakterize sık görülen bir hastalıktır. Bu çalışmanın amacı, cilt prick testi pozitif olan alerjik rinitli hastaların demografik ve klinik özelliklerini ortaya koymaktır.

Gereç ve Yöntem: Pozitif cilt prick testi olan alerjik rinitli hastalar analiz edildi. Test edilen alerjenler: Çayır, tahıl + çayır, ağaçlar 1 (erken çiçeklenenler), ağaçlar 2 (geç çiçeklenenler), ev tozu akarlarıdır (Dermatophagoides pteronyssinus (DP), Dermatophagoides farinae (DF), Tyrophagus putrescentiae (TP), Lepidoglyphus destructor (LD) ve Acarus siro (AS)

Bulgular: Çalışmaya dahil edilen 202 hastanın 145'i kadın (ortalama

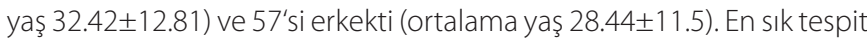
edilen alerjenler; DF, DP, çayır, tahıl + çayır grubuydu. Cilt prick testinin Tyrophagus için pozitifliği istatistiksel olarak kadınlarda anlamlıydı $(p=0.04)$. Nazal akıntı, dispne, kaşıntı, halsizlik, yorgunluk semptomları kadınlarda erkeklere oranla daha fazla bildirildi. DF, DP, TP and LD grubu alerjen duyarlıı̆̆ı ev hanımlarında istatistiksel olarak anlamlı bulundu ( $p<0.05)$. Dispne, hışıltılı solunum ve kaşıntı ev hanımlarında istatistiksel olarak daha sık bulundu $(p<0.05)$.

Sonuç: Ev hanımları, ev tozu akarlarına bağlı alerjik rinit gelişimi için riskli meslek grubundadır.

Anahtar Sözcükler: Alerjik rinit; ev hanımları; mesleki hastalık; cilt prick testi.

Corresponding (illetişim): Tarkan Özdemir, Sağlık Bilimleri Üniversitesi, Dr. Abdurrahman Yurtaslan Onkoloji Eğitim ve Araştırma Hastanesi, Göğüs Hastalıkları Kliniği, Ankara, Turkey

E-mail (E-posta): tabiptarkan@hotmail.com

Received (Geliş Tarihi): 14.06.2019 Accepted (Kabul Tarihi): 02.09.2019 
$\mathrm{T}$ he prevalence of allergic diseases is known to be increasing in all over the world each year. ${ }^{[1]}$ Allergic rhinitis (AR), defined as the presence of at least one or more of the symptoms of sneezing, nasal congestion, rhinorrhea and obstruction, is one of the major forms of allergy affecting approximately $20 \%$ of population. ${ }^{[2,3]}$ The diagnosis of AR generally depends on the clinical characteristics of the disease, laboratory tests such as prick tests and response to pharmacotherapy. ${ }^{[4]}$ The symptoms of AR may deteriorate the life quality of patients and create an economical burden.

Skin prick test (SPT) is a simple, inexpensive, and quick test that is usually preferred to confirm atopy and to identify allergens in patients with IgE-mediated hypersensitivity. ${ }^{[5,6]}$ In this study we aimed to determine the general demographical and clinical features of patients with AR having positive SPT results. We believe that defining clinical features is important to determine etiological contributors and prophylactic measures.

\section{Materials and Method}

\section{Study design and Patient selection}

This study was performed in Corum Chest Diseases Department of State Hospital between December 2011 and December 2012.Patients diagnosed with AR and having SPT recorded results were analyzed retrospectively.

\section{Skin prick test (SPT) and interpretation}

Skin prick test was performed by a single physician and evaluated by the same person. SPT was performed to 9 allergens that were most commonly defined in society using the SPT (Allergopharma, Merck, Reinbek, Germany) with positive control (histamine) and a negative control (distilled water).

Positive and negative control solutions and solutions containing allergen were added drop wise to the patient's forearm flexor surface and the patient was soaked in the middle of each of the drops with a lancet (Abello, Denmark). Approximately 15 minutes later, the reaction occurring on the patient's arm was evaluated by a specialist using the following criteria: ${ }^{[7]}$

Largest size of the wheal diameter with at least $3 \mathrm{~mm}$ was regarded as positive, if the control solutions showed expected result (wheal size at least $3 \mathrm{~mm}$ for the positive control, histaminedihydrochloride $10 \mathrm{mg} / \mathrm{mL}$, and less than 3 $\mathrm{mm}$ for the negative control, allergen solvent). Patient was excluded if the responses to control solutions were not adequate.

The allergens tested were: grasses (velvet grass, fruit grass, crazy grass, meadow timothy grass tail, forest grass, tea leaf), cereal grasses (in addition to grasses, barley, oats, rye, wheat), trees 1 mix (early flowering: alder, elm, hazelnut, willow, poplar), trees 2 mix (late flowering: birch, beech, oak, plane), house-dust mites [HDM: Dermatophagoides pteronyssinus (DP), Dermatophagoides farinae (DF)], tyrophagus putrescen- tiae (TP), lepidoglyphus destructor (LD) and acarus siro (AS). AC, LD and TP are also known as storage mites.

Among 600 patients having AR examined with SPT; totally 202 patients (33.67\%) were reported to have at least one positivity. The demographic features and general characteristics of those 202 patients (145 female and 57 male) were recorded. The patients were asked for the symptoms, smoking history and occupation.

Inclusion criteria: Patients with endurance reaction of at least 3 $\mathrm{mm}$ against any allergen were included in the study. Systemic corticosteroids (4 weeks), intranasal corticosteroids (2 weeks), oral antihistamine (1 week), and topical nasal decongestant (1 day prior) were ensured to be discontinued prior to the application of skin prick test.

Exclusion critera: Patients having positive results with negative control were also excluded from the study. Uncontrolled asthma by predicted peak expiratory flow rate (PEF $<70 \%)$, recent history of respiratory tract infection within the previous weeks and pregnancy, lactation were the other factors fort the exclusion criteria.

\section{Ethical consideration}

The study was approved by the local ethics committee (decision number: 2018-04/45) and written informed consent was obtained from the participants.

\section{Statistical analysis}

Statistical analysis was performed by using the statistical package for the social sciences (SPSS) version 21 (SPSS Inc., Chicago, IL, USA). Comparison of quantitative variables between the study groups was performed using one-way analysis of variance for comparing three groups when normally distributed and Kruskal Wallis (when indicated). For comparing categorical data, Chi-square $\left(\mathrm{X}^{2}\right)$ test was performed and Fisher's exact test was used when appropriate. Continuous variables were presented as mean \pm standard deviation and categorical data were presented as a number or frequencies when appropriate. $\mathrm{P}<0.05$ was considered statistically significant.

\section{Results}

Totally 202 patients, 145 female (with a mean age of $32.42 \pm 12.81$ years) and 57 male (with a mean age of $28.44 \pm 11.5$ years), with AR and positive SPT were included in the study. Among study participants 177 were non-smoker and 25 were ex-smoker. The mean age of the study participants was $31.00 \pm 12.63$ years (range: 18-67 years).

Out of 202 patients, 78 were housewives, 57 were students, and 67 were having other jobs (teacher, farmer, policeman, coiffeur, cook and repairman). Distribution of allergen agents among genders are summarized in Table 1. The most common allergens determined were; DF, DP, creals+ grasses and grasses (Table 1). There was statistically significant difference between genders in only tyrophagus which was more com- 


\section{Table 1. Allergenic sensitivity determined among genders}

\begin{tabular}{lcccc} 
& $\begin{array}{c}\text { Number } \\
\text { of patients } \\
\text { with } \\
\text { positive } \\
\text { results }\end{array}$ & $\begin{array}{c}\text { Female } \\
(\mathbf{n}=\mathbf{1 4 5})\end{array}$ & $\begin{array}{c}\text { Male } \\
(\mathbf{n}=\mathbf{5 7})\end{array}$ & $\mathbf{p}$ \\
& 104 & 69 & 35 & 0.09 \\
\hline Grasses & 106 & 71 & 35 & 0.12 \\
Cereals + grasses & 15 & 9 & 6 & 0.37 \\
Trees 1 & 12 & 6 & 6 & 0.10 \\
Trees 2 & 112 & 86 & 26 & 0.09 \\
Der. farinae & 117 & 89 & 28 & 0.11 \\
Der. pteronyssinus & $\mathbf{6 8}$ & $\mathbf{5 5}$ & $\mathbf{1 3}$ & $\mathbf{0 . 0 4}$ \\
Tyrophagus putrescentiae & 68 & 53 & 15 & 0.18 \\
Lepidoglyphus destructor & 23 & 17 & 6 & 1.00 \\
Acarus siro & & & & \\
\hline
\end{tabular}

Table 2. Symptoms among genders

\begin{tabular}{lcccc} 
& Total & $\begin{array}{c}\text { Female } \\
(\mathbf{n = 1 4 5})\end{array}$ & $\begin{array}{c}\text { Male } \\
(\mathbf{n}=\mathbf{5 7})\end{array}$ & $\mathbf{p}$ \\
\hline Nasal stiffness & 141 & 102 & 39 & 0.86 \\
Nasal discharge & $\mathbf{1 5 0}$ & $\mathbf{1 0 1}$ & $\mathbf{4 9}$ & $\mathbf{0 . 0 2}$ \\
Nasal itching & 155 & 107 & 48 & 0.14 \\
Sneezing & 177 & 124 & 53 & 0.23 \\
Postnasal drip & 111 & 86 & 25 & 0.058 \\
Postnasal itching & 107 & 79 & 28 & 0.53 \\
Burning in eyes & 147 & 107 & 40 & 0.60 \\
Dyspnea & $\mathbf{7 9}$ & $\mathbf{6 2}$ & $\mathbf{1 7}$ & $\mathbf{0 . 0 1 1}$ \\
Wheezing & 83 & 59 & 24 & 1.0 \\
Cough & 110 & 84 & 26 & 0.11 \\
Skin rash & 28 & 22 & 6 & 0.50 \\
Itching & $\mathbf{5 5}$ & $\mathbf{4 7}$ & $\mathbf{8}$ & $\mathbf{0 . 0 0 8}$ \\
Weakness-tiredness & $\mathbf{9 6}$ & $\mathbf{7 9}$ & $\mathbf{1 7}$ & $\mathbf{0 . 0 0 2}$ \\
Itching on ear & 82 & 65 & 17 & 0.07 \\
\hline
\end{tabular}

mon in females $(p=0.04)$. All other allergens were determined to be similar between 2 genders. The symptoms are summarized in Table 2 . The most common symptoms were sneezing, nasal itching, nasal discharge, burning in eyes and nasal stiffness. When symptoms were compared among genders, nasal discharge, dyspnea, itching and weakness-tiredness were reported to be more common in females (Table 2).

Among study participants, 78 were housewives and they were compared with women attached to other occupations (non-housewives) $(n=67)$ regarding the symptoms and allergenic sensitivity (Tables 3 and 4). Grasses and creals + grasses were statistically significantly less common while $D F, D P, T P$ and LD were significantly more common in housewives $(p<0.005)$. Dyspnea, wheezing and itching were significantly more common in housewives compared with the non- housewives $(p<0.005)$.
Table 3. Comparison of allergenic sensitivity between housewives and non-housewives

\begin{tabular}{lccc} 
& $\begin{array}{c}\text { Housewife } \\
(\mathbf{n}=\mathbf{7 8})\end{array}$ & $\begin{array}{c}\text { Non-housewife } \\
(\mathbf{n}=\mathbf{6 7})\end{array}$ & $\mathbf{p}$ \\
\hline Grasses & $\mathbf{3 2}$ & $\mathbf{3 8}$ & $\mathbf{0 . 0 3}$ \\
Cereals grasses & $\mathbf{3 3}$ & $\mathbf{3 9}$ & $\mathbf{0 . 0 3}$ \\
Trees 1 & 3 & 6 & 0.30 \\
Trees 2 & 3 & 3 & 1 \\
Der. farinae & $\mathbf{5 4}$ & $\mathbf{3 2}$ & $\mathbf{0 . 0 2}$ \\
Der. ptero & $\mathbf{5 6}$ & $\mathbf{3 3}$ & $\mathbf{0 . 0 2}$ \\
Tyrophagus putrescentiae & 35 & 20 & 0.09 \\
Lepidoglyphus destructor & $\mathbf{3 5}$ & $\mathbf{1 8}$ & $\mathbf{0 . 0 4}$ \\
Acarus siro & 11 & 6 & 0.44 \\
\hline
\end{tabular}

Table 4. Comparison of symptoms between housewives and non-housewives

\begin{tabular}{lccc} 
& $\begin{array}{c}\text { Housewife } \\
(\mathbf{n}=\mathbf{7 8})\end{array}$ & $\begin{array}{c}\text { Other women } \\
(\mathbf{n}=\mathbf{6 7})\end{array}$ & $\mathbf{p}$ \\
\hline Nasal stiffness & 53 & 50 & 0.20 \\
Nasal discharge & 52 & 50 & 0.17 \\
Nasal itching & 60 & 48 & 0.85 \\
Sneezing & 67 & 58 & 0.49 \\
Postnasal drip & 49 & 37 & 0.49 \\
Postnasal itching & 45 & 35 & 0.87 \\
Burning in eyes & 59 & 49 & 1.00 \\
Dyspnea & $\mathbf{4 4}$ & $\mathbf{1 9}$ & $\mathbf{0 . 0 0 3}$ \\
Wheezing & $\mathbf{4 0}$ & $\mathbf{2 0}$ & $\mathbf{0 . 0 2}$ \\
Cough & 47 & 37 & 0.86 \\
Skin rash & 13 & 9 & 0.82 \\
Itching & $\mathbf{3 2}$ & $\mathbf{1 5}$ & $\mathbf{0 . 0 3}$ \\
Weakness-tiredness & 47 & 30 & 0.22 \\
Itching on ear & 38 & 28 & 1.00 \\
\hline
\end{tabular}

\section{Discussion}

In this study we evaluated the SPT results among patients with $A R$ and we determined that the most common allergen agents among patients with AR were HDM and cereals+grasses pollens. There was not a gender difference regarding allergenic sensitivity except TP which was more common in females. Pollen allergies were reported to be seasonal more commonly, but mite allergies were perennial as expected. When the presence of symptoms were compared; nasal discharge, dyspnea, itching and weakness-tiredness were more common in females than males. We also determined that DF, $D P, T P$ and LD were statistically significantly more common in housewives compared with non.

In previous studies, the distribution of allergens among patients with respiratory allergies was investigated. In a metaanalysis, SPT was defined as accurate in discriminating subjects with or without $A R{ }^{[8]}$ In a recent multicenter study in 
Korea on 28954 patients with suspected respiratory allergies, DF and DP were reported as the most commonly sensitized allergens. In that study $53 \%$ of the participants were female and $45.3 \%$ of study participants had at least one positivity in their skin prick tests. ${ }^{[9]}$ In another study from our country, among 7492 patients with clinical symptoms of asthma and/or AR and tested for 7 allergens with SPT, the atopy prevalence was $32.2 \%$ and Phleum pratense, DP and Artemisia vulgaris were the most common 3 allergens that were enough to identify at least $95 \%$ of the sensitized subjects. ${ }^{[10]}$ In our study, 202/600 (33.6\%) of patients were having positive SPT results. We performed the test with 9 allergens but $70 \%$ were detectable with the test having 4 determinants while $92 \%$ were detectable with the test having 6 allergens.

In our study, we determined that house dust mites and pollens were the most common allergens in patients with AR. Similar with our results Holopainen et al. ${ }^{[1]]}$ reported that house dusts and pollens were the most common allergens that were present in about $40 \%$ of patients with allergic rhinitis. Lou et al. also reported that house dust mites were the most common allergens determined in patients with $A R{ }^{[12]}$

Wang et al. reported that there was not any gender difference concerning the allergen sensitivity determined with SPT in 340 cases with AR. ${ }^{[13]}$ We also did not determine any differences between genders regarding the allergen agents except TP which was more common in females. Khazaei et al. ${ }^{[14]}$ reported that smoking did not affect the SPT reactivity to pollen and weeds aeroallergens. Since most of our patients were non-smoker we could not analyze the effects of smoking on SPT results.

Although not studied before obviously, we believe that housewives are also in an increased risk for occupational diseases since they work in wet places frequently, they are exposed to chemicals in cleaners, and they do not use protective equipments in general. Housewives work at indoor conditions and human activities are influenced by the differential sensitization to house dust mites and storage mites. The data about the allergens in housewives is limited. DP and DF were suggested to be more closely associated with house dust mites which may be the main reason of our results determining these allergens more commonly in housewives. ${ }^{[15,16]}$ The housewives spent most of their time at home and they are exposed to the mites more commonly. Moreover, detergents used at home may also facilitate the allergic reactions with their irritant effects. Tee et al. also defined that DP and LD were among the most commonly determined skin allergens in 279 United Kingdom bakery workers. ${ }^{[17]}$ Since one of the main working places of housewives are kitchens, these results are also supporting our findings.

TP was shown to induce allergic pulmonary response in a murine model. ${ }^{[18]}$ Even though we did not analyze the presence of asthma in those patients, we determined that TP was more common in housewives and dyspnea was also more common in that group of patients supporting this data indi- rectly. Moreover, dyspnea was present in all patients having positive results for TP. In a study in Turkey, in Kutahya, the prevalence of domestic mites was found to be $18.05 \%$, while T. putrescentiae was found higher with a rate of $43.96 \% .^{[19]}$ The other mites were found as $D$. pteronyssinus with a rate of $31.03 \%$, A. siro with a rate of $13.79 \%$, and L. destructor, G. domesticus and Cheyletus species with a rate of approximately $2 \%$. Regarding this data, it may be suggested that, TP should be added to the prick test panel.

The strength of our study is that it contains a relatively high number of symptoms asked and skin allergens investigated. However there are still several limitations. Socio-cultural level, or monthly incomes were not asked to the patients that may also affect the atopic conditions, and response. Secondly, although skin prick test performed in this study is commonly used in allergy practice, it also has some disadvantages such as its reliability depends largely on the allergists performing the test and good compliance of the subjects.

In conclusion; we determined the most common allergens, and the most common symptoms in patients with allergic rhinitis. In SPT, the most common allergens should be taken into account for the correct diagnosis and cost-affectivity. We showed that mite allergies were more common in housewives. Moreover these allergies were reported to be more commonly associated with asthma. Larger, prospective studies are warranted to define the role of skin prick test in atopic patients with different job groups.

Conflict of interest: There are no relevant conflicts of interest to disclose.

\section{References}

1. Linneberg A. The increase in allergy and extended challenges. Allergy. 2011; 66 (Suppl): 95. 1-3.

2. Prasad R, Verma SK, Dua R, Kant S, Kushwaha RA, Agarwal SP. A study of skin sensitivity to various allergens by skin prick test in patients of nasobronchial allergy. Lung India. 2009; 26: 70-73.

3. Khazaei HA, Moulaei NA, Tabatabaei SNA, Khazaei A, Khosravi A. The Effect of Smoke Cigarette on Immune Responses of AR Patients. Biosc Biotech Res Asia. 2014; 11(2): 925-30

4. Wheatley LM, Togias A. Clinical practice. Allergic rhinitis. N Engl J Med. 2015; 29; 372(5): 456-63.

5. Liu Y, Peng J, Zhou Y, Cui Y. Comparison of atopy patch testing to skin prick testing for diagnosing mite-induced atopic dermatitis: a systematic review and meta-analysis. Clin Transl Allergy. 2017 Nov 29; 7: 41.

6. Chiriac AM, Bousquet J, Demoly P. In vivo methods for the study and diagnosis of allergy. In: Adkinson NF Jr, Bochner BS, Burks AW, Busse WW, Holgate ST, Lemanske RF, O'Hehir RE Jr, editors. Middleton's allergy principles and practice. 8th ed. Philadelphia: Elsevier; 2013. pp. 1119-1132.

7. Bousquet J, Heinzerling L, Bachert C, Papadopoulos NG, Bousquet PJ, Burney PG, Canonica GW, Carlsen KH, Cox L, Haahtela T, Lodrup Carlsen KC, Price D, Samolinski B, Simons FE, Wickman M, Annesi-Maesano I, Baena-Cagnani CE, Bergmann KC, BindslevJensen C, Casale TB, Chiriac A, Cruz AA, Dubakiene R, Durham 
SR, Fokkens WJ, Gerth-van-Wijk R, Kalayci O, Kowalski ML, Mari A, Mullol J, Nazamova-Baranova L, O'Hehir RE, Ohta K, Panzner P, Passalacqua G, Ring J, Rogala B, Romano A, Ryan D, Schmid-Grendelmeier P, Todo-Bom A, Valenta R, Woehrl S, Yusuf OM, Zuberbier T, Demoly P; Global Allergy and Asthma European Network; Allergic Rhinitis and its Impact on Asthma. Practical guide to skin prick tests in allergy to aeroallergens. Allergy. 2012 Jan;67(1):18-24.

8. Nevis IF, Binkley K, Kabali C. Diagnostic accuracy of skin-prick testing for allergic rhinitis: a systematic review and meta-analysis.Allergy Asthma Clin Immunol. 2016 Apr 27; 12:20.

9. Kang MG, Kim MY, Song WJ, Kim S, Jo EJ, Lee SE, Kwon JW, Lee SM, Park CS, Park HK, Park HW, Chang YS, Lee J, Lee YM, Jee YK, Lee JM, Choi IS, Cho SH. Patterns of Inhalant Allergen Sensitization and Geographical Variation in Korean Adults: A Multicenter Retrospective Study.Allergy Asthma Immunol Res. 2017 Nov; 9(6): 499-508

10. Comert S, Demir AU, Karakaya G, Kalyoncu AF. Minimum prick test panel for adult patients with asthma and rhinitis in Ankara, Turkey. J Asthma. 2014 May; 51(4): 417-22.

11. Holopainen E, Salo OP, Tarkiainan E, Malmberg H. The most important allergens in allergic rhinitis. Acta Otolaryngol. 1979; 360: $16-8$.

12. Lou H, Ma S, Zhao Y, Cao F, He F, Liu Z, Bousquet J, Wang C, Zhang $L$, Bachert $C$. Sensitization patterns and minimum screening pan- els for aeroallergens in self-reported ARin China.Sci Rep. 2017 Aug 24; 7(1): 9286.

13. Wang Z, Gao Y, Zheng Y.Analysis on allergens in patients with ARin Urumqi Xinjiang. Lin Chung Er Bi Yan Hou Tou Jing Wai Ke Za Zhi. 2015 Aug;29(15):1328-31.

14. Khazaei HA, Khazaei B, Dashtizadeh GA, Mohammadi M. Cigarette Smoking and Skin Prick Test in Patients With Allergic Rhinitis. Int J High Risk Behav Addict. 2015 Sep 1;4(3):e23483.

15. Thomas WR, Smith WA, Hales BJ. The allergenic specificities of the house dust mite. Chang Gung Med J. 2004;27: 563-569.

16. Cui Y, Zhou P, Peng J, Peng M, Zhou Y, Lin Y, Liu L. Cloning, sequence analysis, and expression of CDNA coding for the major house dust mite allergen, Der f 1, in Escherichia coli. Braz J Med Biol Res. 2008; 41(5): 380-388.

17. Tee RD, Gordon DJ, Gordon S, Crook B, Nunn AJ, Musk AW, Venables KM, Taylor AJ. Immune response to flour and dust mites in a United Kingdom bakery. Br J Ind Med. 1992 Aug;49(8):581-7.

18. Nuñez NK, da Cunha AA, Dos Santos Dutra M, Barbosa GL, Morassutti AL, de Souza RG, Vargas MH, Antunes GL, Silveira JS, da Silva GL, Pitrez PM. Acute and chronic exposure to Tyrophagus putrescentiae induces allergic pulmonary response in a murine model. Asia Pac Allergy. 2016 Jan; 6(1): 48-55.

19. Akdemir C, Gurdal H. House dust mite in Kutahya, Turkey. [Turkish] Turkiye Parazitol Derg 2005;29(2):110-115. 